\title{
An experimental study on the effect of rolling shutters on the field measurements of airborne sound insulation of façades
}

\author{
César Díaz*, Alexander Díaz, M.A. Navacerrada \\ Grupo de Acústica Arquitectónica, Escuela Técnica Superior de Arquitectura de Madrid, Spain \\ Universidad Politécnica, Avda. Juan de Herrera 4, 28040 Madrid, Spain
}

\section{A R T I C L E I N F O}

\section{Article history}

Received 31 January 2012

Received in revised form 5 July 2012

Accepted 9 July 2012

Available online 22 August 2012

\section{Keywords:}

Airborne sound insulation

Façades

Windows

Shutter

Rolling shutter box

Traffic noise

\begin{abstract}
A B S T R A C T
The façade is the visible part of a building, and generally consists of various different constructive systems. The sound reduction index of the closing elements for the openings on a room's façade is a determining factor in the sound insulation from airborne noise inside the space. Windows are the transparent part of the façade, and to improve their thermal behaviour and control solar radiation, they are often fitted with a series of external and internal protections such as shutters, slats and blinds.

This work contains a summary of studies carried out using field measurements of airborne sound insulation on façades in rooms, in application of the standard UNE-EN ISO 140-5:1999. In all the rooms the windows were fitted with shutter boxes and rolling shutters, and the acoustic tests were made with the shutter in two positions (extended and fully retracted). The results were analysed considering the window opening system (openable or sliding) and the type of glass pane (monolithic or insulating glass unit, IGU). In the case of sliding windows, the airborne sound insulation of façades is greater when the shutter is extended than when it is retracted, and this should be taken into account when applying the aforementioned standard.
\end{abstract}

\section{Introduction}

The façade is the visible part of a building which must guarantee thermal and acoustic protection and satisfy the needs for lighting, watertightness, fire resistance and stability in order to ensure minimum conditions of habitability on the spaces inside. The façade of a room is usually composed of different construction elements and the acoustic transmission through them depends on the acoustic transmission of each one of their components. The sound reduction index of the closure of the openings on the façade of the space is a key factor in the airborne sound insulation of a façade.

The sound reduction index in windows, including the shutter and the shutter box, has been studied in different laboratories [1-3]. In Ref. [3], it has been shown that on a window with a shutter box, when the shutter is extended, the system formed by the window and the shutter operates acoustically like a system of various partitions, and the results differ according to the window opening system. In openable windows, when the shutter is extended the weighted acoustic reduction rate of $R_{w}+C_{t r}$ is slightly lower than when the shutter is retracted; however, in the case of

\footnotetext{
* Corresponding author. Tel.: +34 913366542; fax: + 34913366554.

E-mail address: cesar.diaz.sanchidrian@upm.es (C. Díaz).
}

sliding windows, the weighted acoustic reduction rate $R_{w}+C_{t r}$ is $2 \mathrm{~dB}$ greater when the shutter is extended than when it is retracted.

This work shows the experimental results of the measurements for sound insulation from airborne noise on flat façades in around 100 rooms for built-in shutters, with the box installed behind the lintel [4]. Fig. 1 shows a section of the integrated-type windows on which the acoustics measurements were carried out. The window opening system is either openable or horizontal sliding, and the type of glass is monolithic or insulating glass unit (IGU). On each façade the acoustic measurements were taken with the window closed, in two positions: with the shutter extended or fully retracted, according to the specifications of standard UNE-EN ISO 140-5:1999 [5]. In most situations the windows were not classified according to their air permeability [6].

The acoustic magnitude calculated is the standardised sound level difference of the façade $D_{2 m, n T}$ determined by the equation:

$D_{2 m, n T}=L_{1.2 m}-L_{2}+10 \lg \frac{T}{0.5} \quad d B$

where $L_{1.2 \mathrm{~m}}$ is the exterior sound pressure level, $2 \mathrm{~m}$ in front of the façade; $L_{2}$ is the average space-time value of the sound pressure level on the inside of the receiving room; and $T$ is the reverberation time in the receiving room. 

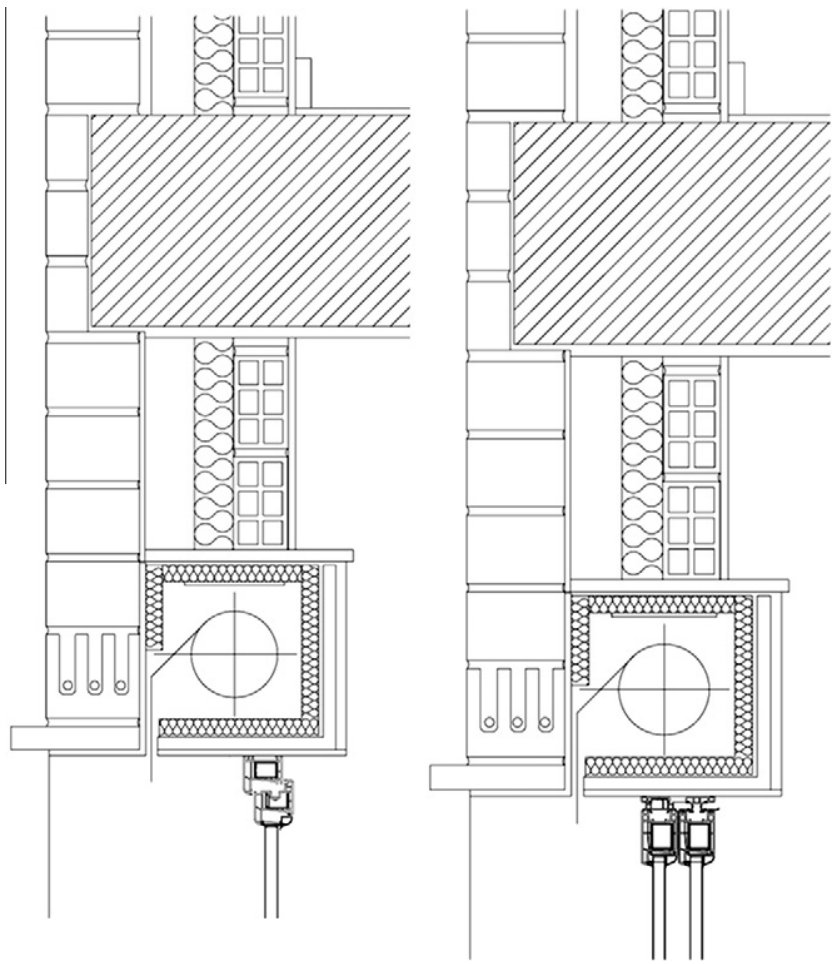

Fig. 1. Section of integrated-type windows on which the acoustic measurements of the façades were taken, with the shutter box installed behind the lintel.

The apparent sound reduction index of the façade, $R_{f}^{\prime}$, in $\mathrm{dB}[7]$ is calculated by:

$R_{f}^{\prime}=D_{2 m, n T}-\Delta L_{f s}-101_{g} 0.32 \frac{V}{S_{f}}$

where $V$ is the volume of the receiving room, in $\mathrm{m}^{3} ; S_{f}$ is the total area of the façade, in $\mathrm{m}^{2}$; and $\Delta L_{f s}$ is the level difference due to the shape of the façade, in $\mathrm{dB}$.

In this work, only flat façades of spaces have been studied, $\Delta L_{f s}=0$; without air vents, $D_{n e}=0$. The indirect transmissions have been estimated in a global manner, subtracting $2 \mathrm{~dB}$ from the global sound reduction index of the rigid and heavy element of the façade, $R_{\text {wall }}$. The apparent sound reduction index of the window, $R_{w} i n^{\prime}$, can be obtained from the apparent sound reduction index of the façade, $R_{f}^{\prime}$, from the equation:

$R_{f}^{\prime}=-10 \lg \left(\frac{S_{\text {win }}}{S_{f}} \cdot 10^{-0.1 R_{\text {win }}^{\prime}}+\frac{S_{\text {wall }}}{S_{f}} \cdot 10^{-0.1\left(R_{\text {wall }}-2\right)}\right) d B$

\section{Experimental results}

The acoustic insulation from airborne noise on the façades of rooms has been measured in inhabited buildings located in different parts of Spain, according to the guidelines in standard UNE-EN ISO 140-5:1999. The standardised sound level difference of the façade, $D_{2 m, n T}$, was determined in $1 / 3$ octave bands from $100 \mathrm{~Hz}$ to $5 \mathrm{kHz}$, and the global result, $D_{2 m, n T}\left(C ; C_{t r}\right)$, is expressed in accordance with EN ISO 717-1 [8,9]. The accuracy of the measuring equipment was verified periodically in accredited calibration laboratories, and the repeatability tests conducted are satisfactory in all the frequency bands [10].

This section shows the results obtained in the tests. They have been grouped according to the window closing system and the type of glazing. The Tables 1-4 show the geometric dimensions of the rooms and the values of weighted standardised sound level difference, $D_{2 m, n T, w}\left(C ; C_{t r}\right)$, of the façades, and the weighted apparent sound reduction index with the spectrum adaptation term of the windows, $R_{w}^{\prime}+C t r$ in $\mathrm{dB}$, with the shutter retracted or fully extended. In all the cases studied, the shutter was installed on the outer part of the room, and the window frames were made of aluminium or PVC. The cases where the windows had a single pane of glass correspond to housing units built prior to 1980. In the rooms studied, the ratio between the area of the opening on the façade and the total area of the façade varies between 0.1 and 0.4 .

An essential aspect of a field measurement is to give the measured magnitude and the uncertainty associated to such a magnitude. In the calculus of the uncertainty it is very usual to follow the uncertainty propagation method as described in the Guide to the expression of Uncertainty in Measurements (GUMs) [11]. Other option is the numerical calculus based on the distribution propagation method by means of Monte Carlo simulation. This method is numerical and in agreement with the GUM principles. In our laboratory, we use Excel for the Monte Carlo simulation. A detailed description of the numerical method has been already published in Ref. [12]. One important factor to be considered in Monte Carlo simulation is the number of repetitions of the process. The differences observed in the final values are not bigger than $0.1 \mathrm{~dB}$ above 1000 simulations, then in order to make faster the calculus process we consider that 1000 simulations is adequate. On the other hand, the uncertainty evaluation process encompasses a number of influences quantities that affect the result obtained for the measurand. In this line, the measurement procedures following standards ISO 140-5 require the measured of time-averaged sound pressure levels, $L_{1}$ and $L_{2}$, at a number of different points in a room and their averaged. The maximum uncertainty of the final magnitudes derived from the field measurements is mainly coming from the $L_{2}$ average. Previously, we have analysed the room sound field based on the standard deviation of $L_{2}$ [13], we have also compared to the theoretical models [14]. The high $L_{2}$ standard deviation values correspond to the low frequencies: the exact values are mainly fixed by the microphone positions and the façade characteristics $[15,16]$. At intermediate frequencies (from 400 to $4000 \mathrm{~Hz}$ ) the $L_{2}$ standard deviation is almost independent on the volume and room configuration [16]. So, this is the behaviour we found when the uncertainty associated to $D_{2 m, n T}$ is calculated by the Monte Carlo method. At low frequency the uncertainty is depending of the measurement configuration and is ranging between 2 and $6 \mathrm{~dB}$ and it is below $1 \mathrm{~dB}$ when the frequency band is above $400 \mathrm{~Hz}$.

Following with uncertainty calculus, one of the most remarkable advantages of the Monte Carlo method is that allows us an easy calculus of the uncertainty associated to single-number magnitudes as for example $D_{2 m, n T, w}+C_{t r}$ [11] . The data necessary for the calculus of the uncertainty of the single-number magnitudes is generated during the Monte Carlo simulation process of the uncertainty associated to $D_{2 m, n T}$. During the simulation for each frequency band we generated 1000 values of $D_{2 m, n T}$ (so we have 1000 groups containing 18 values of $D_{2 m, n T}$ between 100 and $5000 \mathrm{~Hz}$ ). One value of the single-number magnitude can be calculated comparing each group of 18 values of the evaluated parameter to the reference curve according to standard ISO 717-1. At the end of the process, we have 1000 values of the single-number magnitude. Supposing the distribution as normal, the mean value is a good estimation of the single-number magnitude and the combined uncertainty can be considered as the standard deviation of the distribution. Following a similar process the uncertainty associated to $C_{t r}$ can be evaluated. From these values it is easy to evaluated the combined uncertainties associated to $\left(D_{2 m, n T, w}+C_{t r}\right)$ and so, the expanded uncertainty multiplying by the factor $k=2$. The final expanded uncertainty is ranging between 1 and $2 \mathrm{~dB}$ for single number magnitudes as for example $\left(D_{n T, \mathrm{w}}+C\right)$ and $\left(D_{2 m, n T w}+\right.$ $C_{t r}$ ). These values are also indicative of a reasonable evaluation of the uncertainty. 
Table 1

Geometric dimensions of rooms and the calculated weighted acoustic magnitude in the case of façades with sliding horizontal windows and monolithic glass.

\begin{tabular}{|c|c|c|c|c|c|c|c|}
\hline \multicolumn{4}{|c|}{ Sliding windows with monolithic glass } & \multirow{2}{*}{$\begin{array}{l}\text { Façade shutter } \\
\text { retracted } \\
D_{2 m, n T, w}\left(C ; C_{t r}\right) \mathrm{dB}\end{array}$} & \multirow{2}{*}{$\begin{array}{l}\text { Façade shutter } \\
\text { extended } \\
D_{2 m, n T, w}\left(C ; C_{t r}\right) \mathrm{dB}\end{array}$} & \multirow{2}{*}{$\begin{array}{l}\text { Window shutter } \\
\text { retracted } \\
R_{w}^{\prime}+C_{t r}, \mathrm{~dB}\end{array}$} & \multirow{2}{*}{$\begin{array}{l}\text { Window shutter } \\
\text { extended } \\
R_{w}^{\prime}+C_{t r}, \mathrm{~dB}\end{array}$} \\
\hline Test & $\begin{array}{l}\text { Volume } \\
\left(\mathrm{m}^{3}\right)\end{array}$ & $\begin{array}{l}\text { Façade area } \\
\left(\mathrm{m}^{2}\right)\end{array}$ & $\begin{array}{l}\text { Opening area } \\
\left(\mathrm{m}^{2}\right)\end{array}$ & & & & \\
\hline $\mathrm{C}-40 \mathrm{~A}$ & 49.8 & 25.3 & 9.4 & $25(-1 ;-2)$ & $29(-1 ;-4)$ & 21 & 23 \\
\hline C-40B & 32.7 & 18.1 & 2.5 & $28(-1 ;-1)$ & $31(-1 ;-4)$ & 21 & 21 \\
\hline$C-40 C$ & 23.6 & 15.3 & 1.9 & $26(-1 ;-2)$ & $29(-1 ;-4)$ & 18 & 19 \\
\hline $\mathrm{I}-52.03 \mathrm{C}$ & 22.3 & 14.4 & 1.5 & $29(0 ;-1)$ & $33(-1 ;-4)$ & 21 & 22 \\
\hline V-9.02 A & 2.6 & 8.2 & 1.6 & $25(-1.0)$ & $33(-1 ;-2)$ & 18 & 24 \\
\hline V-9.02 B & 23.0 & 7.4 & 1.6 & $27(0 ;-1)$ & $33(-1 ;-3)$ & 19 & 23 \\
\hline V-9.02 C & 22.9 & 7.3 & 1.6 & $27(0 ; 0)$ & $32(0 ;-3)$ & 20 & 22 \\
\hline V-9.02 D & 34.6 & 21.4 & 5.3 & $30(0 ; 0)$ & $35(-1 ;-4)$ & 27 & 28 \\
\hline C-14.02 B & 31.0 & 8.8 & 2 & $27(0 ;-1)$ & $31(-1 ;-3)$ & 19 & 21 \\
\hline C-14.02 C & 17.8 & 15.0 & 1.1 & $27(-1 ;-1)$ & $30(-1 ;-2)$ & 19 & 21 \\
\hline $\mathrm{C}-20 \mathrm{~A}$ & 47.8 & 24.8 & 8.4 & $26(-1 ;-3)$ & $27(-1 ;-4)$ & 20 & 20 \\
\hline V-9.02 A & 25.6 & 8.2 & 1.6 & $25(-1 ; 0)$ & $33(-1 ;-2)$ & 18 & 24 \\
\hline V-9.01 A & 22.6 & 15.8 & 2.2 & $22(-2 ; 0)$ & $30(-1 ;-1)$ & 17 & 24 \\
\hline$C-16 C$ & 23.1 & 14.8 & 1.9 & $25(0 ;-1)$ & $33(-2 ;-6)$ & 18 & 21 \\
\hline $\mathrm{C}-38.01 \mathrm{~A}$ & 37.7 & 19.7 & 2.4 & $26(0 ;-1)$ & $29(-1 ;-3)$ & 18 & 19 \\
\hline V-4.01 A & 29.3 & 7.1 & 2.2 & $24(-1 ; 0)$ & $28(-1 ;-2)$ & 18 & 20 \\
\hline I-32.02 C & 33.7 & 18.9 & 5.3 & $25(0 ;-1)$ & $28(-1 ;-3)$ & 21 & 22 \\
\hline $\mathrm{I}-49.01 \mathrm{~B}$ & 22.5 & 6.8 & 1.3 & $27(-1 ;-1)$ & $29(-1 ;-2)$ & 19 & 20 \\
\hline I-49.04 B & 22.2 & 6.8 & 1.3 & $26(-1.0)$ & $31(0 ;-2)$ & 19 & 22 \\
\hline I-49.05 B & 22.1 & 15.8 & 1.3 & $25(0 ;-1)$ & $32(0 ;-2)$ & 17 & 23 \\
\hline
\end{tabular}

Table 2

Façades with sliding horizontal windows and IGU, geometric dimensions of rooms and the calculated weighted acoustic magnitude.

\begin{tabular}{|c|c|c|c|c|c|c|c|}
\hline \multicolumn{4}{|c|}{ Sliding window with IGU } & \multirow{2}{*}{$\begin{array}{l}\text { Façade shutter } \\
\text { retracted } \\
D_{n T, w}\left(C ; C_{t r}\right) \mathrm{dB}\end{array}$} & \multirow{2}{*}{$\begin{array}{l}\text { Façade shutter } \\
\text { extended } \\
D_{n T, w}\left(C ; C_{t r}\right) \mathrm{dB}\end{array}$} & \multirow{2}{*}{$\begin{array}{l}\text { Window shutter } \\
\text { retracted } \\
R_{w}^{\prime}+C_{t r}, \mathrm{~dB}\end{array}$} & \multirow{2}{*}{$\begin{array}{l}\text { Window shutter } \\
\text { extended } \\
R_{w}^{\prime}+C_{t r}, \mathrm{~dB}\end{array}$} \\
\hline Test & $\begin{array}{l}\text { Volume } \\
\left(\mathrm{m}^{3}\right)\end{array}$ & $\begin{array}{l}\text { Façade area } \\
\left(\mathrm{m}^{2}\right)\end{array}$ & $\begin{array}{l}\text { Opening area } \\
\left(\mathrm{m}^{2}\right)\end{array}$ & & & & \\
\hline $\mathrm{C}-10 \mathrm{C}$ & 27.4 & 16.9 & 1.9 & $36(-1 ; 4)$ & $39(-2 ;-6)$ & 32 & 33 \\
\hline C-10D & 35.6 & 31.6 & 1.9 & $37(-2 ;-5)$ & $39(-2 ;-5)$ & 32 & 34 \\
\hline C-2.02 A & 48.0 & 1.4 & 4.3 & $37(-1 ;-4)$ & $40(-2 ;-6)$ & 33 & 34 \\
\hline C-2.02 B & 35.7 & 20.4 & 1.5 & $31(-1 ;-3)$ & $32(-1 ;-4)$ & 28 & 28 \\
\hline $\mathrm{C}-2.02 \mathrm{C}$ & 18.6 & 13.8 & 2.2 & $30(0 ;-3)$ & $31(-2 ;-6)$ & 27 & 25 \\
\hline $\mathrm{C}-2.01 \mathrm{~A}$ & 27.6 & 16.1 & 1.6 & $31(-1 ;-3)$ & $34(-1 ;-4)$ & 28 & 30 \\
\hline C-2.01 B & 16.0 & 12.2 & 1.6 & $30(-1 ;-3)$ & $32(-1 ;-4)$ & 27 & 28 \\
\hline SC-14A & 20.4 & 13.7 & 1.8 & $29(-1 ;-2)$ & $35(-1 ;-4)$ & 27 & 31 \\
\hline SC-14 B & 29.4 & 16.2 & 2.1 & $30(-1 ;-2)$ & $32(-1 ;-5)$ & 28 & 27 \\
\hline SC-14C & 28.5 & 16 & 2.0 & $30(-1 ;-3)$ & $34(-2 ;-5)$ & 27 & 29 \\
\hline C-18B & 43.3 & 17.5 & 2.3 & $27(-1 ;-2)$ & $29(-2 ;-3)$ & 25 & 26 \\
\hline C-18C & 50.0 & 24.8 & 2.1 & $34(-2 ;-4)$ & $34(-2 ;-5)$ & 30 & 31 \\
\hline C-27 A & 25.0 & 8.8 & 1.06 & $25(0 ;-1)$ & $34(-1 ;-4)$ & 24 & 30 \\
\hline C-20G & 37.5 & 19.3 & 1.3 & $28(-1 ;-2)$ & $33(-1 ;-4)$ & 26 & 29 \\
\hline C-16D & 31.9 & 17.3 & 1.8 & $32(0 ;-1)$ & $36(-1 ;-4)$ & 31 & 32 \\
\hline$V-3 A$ & 33.9 & 17.6 & 1.8 & $32(0 ;-2)$ & $39(-1 ;-5)$ & 30 & 34 \\
\hline C-65B & 28.9 & 6.9 & 1.6 & $33(-1 ;-3)$ & $37(-2 ;-5)$ & 30 & 32 \\
\hline $\mathrm{I}-32.01 \mathrm{C}$ & 17.8 & 13.9 & 1.7 & $27(-1 ;-2)$ & $34(-2 ;-5)$ & 25 & 29 \\
\hline I-32.05 B & 18.6 & 12.6 & 1.5 & $30(0 ; 0)$ & $35(-1 ;-4)$ & 30 & 31 \\
\hline I-49.02 B & 18.9 & 13.1 & 2.8 & $24(-1 ;-2)$ & $29(-1 ;-4)$ & 22 & 25 \\
\hline
\end{tabular}

\subsection{Façades with horizontal sliding windows and monolithic glass}

The acoustic tests were carried out in 20 rooms. Sliding windows with monolithic glass are rather uncommon in new residential buildings, basically owing to their low energy efficiency. The windows are glazed by means of a single glass pane with a thickness of $4 \mathrm{~mm}$. When the shutter is extended the system works acoustically in the same way as a system of double panels. According to the values for the mass per unit of area of the shutter and the glass pane, as well as the two distances between the panes of glass and the shutter, the mass-air-mass resonance frequencies [17] are located in the third octave band with a central frequency of $160 \mathrm{~Hz}$ and $200 \mathrm{~Hz}$.

As an example of the results obtained in façades with sliding horizontal windows and monolithic glass Fig. 2 compares the results of the two tests for standardised sound level difference, $D_{2 m, n T}$, on the façade of rooms with the shutter extended and retracted respectively. It can be observed that when the shutter is extended the sound insulation from airborne noise in the frequency bands where the resonance frequencies are located is lower than when the shutter is retracted. For frequencies over $500 \mathrm{~Hz}$ the insulation from airborne noise of façades with the shutter extended is clearly superior to when the shutter is retracted.

\subsection{Façades with horizontal sliding windows and insulating glass unit}

In this type of window, tests were made on 20 façades. The windows are glazed with insulating glass units with a thickness of $4(12) 4 \mathrm{~mm}$; the figure in parentheses is the width of the airfilled cavity. When the shutter is extended, the system functions 
Table 3

Façades with openable windows and monolithic glass: geometric dimensions of rooms and the calculated weighted acoustic magnitude.

\begin{tabular}{|c|c|c|c|c|c|c|c|}
\hline \multicolumn{4}{|c|}{ Openable windows with monolithic glass } & \multirow{2}{*}{$\begin{array}{l}\text { Fagade shutter } \\
\text { retracted } \\
D_{2 m, n T, w}\left(C ; C_{t r}\right) \mathrm{dB}\end{array}$} & \multirow{2}{*}{$\begin{array}{l}\text { Fagade shutter } \\
\text { extended } \\
D_{2 m, n T, w}\left(C ; C_{t r}\right) \mathrm{dB}\end{array}$} & \multirow{2}{*}{$\begin{array}{l}\text { Window shutter } \\
\text { retracted } \\
R_{w}^{\prime}+C_{t r}, \mathrm{~dB}\end{array}$} & \multirow{2}{*}{$\begin{array}{l}\text { Window shutter } \\
\text { extended } \\
R_{w}^{\prime}+C_{t r}, \mathrm{~dB}\end{array}$} \\
\hline Test & $\begin{array}{l}\text { Volume } \\
\left(\mathrm{m}^{3}\right)\end{array}$ & $\begin{array}{l}\text { Fagade area } \\
\left(\mathrm{m}^{2}\right)\end{array}$ & $\begin{array}{l}\text { Opening area } \\
\left(\mathrm{m}^{2}\right)\end{array}$ & & & & \\
\hline I-52.02 B & 17.5 & 5 & 0.9 & $25(-1 ;-2)$ & $28(-1 ;-4)$ & 23 & 24 \\
\hline I-52.02 C & 21.1 & 6.7 & 1.5 & $24(-1 ;-2)$ & $29(-1 ;-4)$ & 22 & 25 \\
\hline I-52.03 B & 19.4 & 5.4 & 0.9 & $27(-1 ;-3)$ & $26(-1 ;-3)$ & 24 & 23 \\
\hline I- $52.04 \mathrm{~B}$ & 23.0 & 6.5 & 2.3 & $25(-1 ;-2)$ & $29(-2 ;-5)$ & 23 & 24 \\
\hline I-32.03 C & 18.8 & 12.8 & 1.5 & $25(-1 ;-1)$ & $29(-1 ;-3)$ & 24 & 26 \\
\hline M-5085 D & 37.6 & 10.4 & 2.4 & $25(-1 ;-2)$ & $26(-1 ;-3)$ & 23 & 23 \\
\hline
\end{tabular}

Table 4

Façades with openable windows and insulating glass unit: geometric dimensions of rooms and the calculated weighted acoustic magnitude.

\begin{tabular}{|c|c|c|c|c|c|c|c|}
\hline \multicolumn{4}{|c|}{ Openable windows with IGU } & \multirow{2}{*}{$\begin{array}{l}\text { Fagade shutter } \\
\text { retracted } \\
D_{2 m, n T, w}\left(C ; C_{t r}\right) \mathrm{dB}\end{array}$} & \multirow{2}{*}{$\begin{array}{l}\text { Fagade shutter } \\
\text { extended } \\
D_{2 m, n T, w}\left(C ; C_{t r}\right) \mathrm{dB}\end{array}$} & \multirow{2}{*}{$\begin{array}{l}\text { Window shutter } \\
\text { retracted } \\
R_{w}^{\text {Prime }}+C_{t r}, \mathrm{~dB}\end{array}$} & \multirow{2}{*}{$\begin{array}{l}\text { Window shutter } \\
\text { extended } \\
R_{w}^{\text {Prime }}+C_{t r}, \mathrm{~dB}\end{array}$} \\
\hline Test & $\begin{array}{l}\text { Volume } \\
\left(\mathrm{m}^{3}\right)\end{array}$ & $\begin{array}{l}\text { Façade area } \\
\left(\mathrm{m}^{2}\right)\end{array}$ & $\begin{array}{l}\text { Opening area } \\
\left(\mathrm{m}^{2}\right)\end{array}$ & & & & \\
\hline M- $5057 \mathrm{~A}$ & 83.8 & 29.9 & 4 & $41(-1 ;-5)$ & $41(-2 ;-6)$ & 28 & 27 \\
\hline M- 5057 B & 36.8 & 17.7 & 1.9 & $41(-2 ;-6)$ & $41(-3 ;-7)$ & 27 & 26 \\
\hline M- $5057 \mathrm{C}$ & 23.0 & 8.5 & 1.5 & $38(-2 ;-5)$ & $38(-2 ;-6)$ & 26 & 25 \\
\hline M- 5057 D & 25.1 & 15.6 & 1.5 & $39(-3 ;-6)$ & $39(-4 ;-8)$ & 26 & 24 \\
\hline C- $9.01 \mathrm{~A}$ & 27.3 & 17 & 2 & $37(-1 ;-4)$ & $37(-1 ;-5)$ & 27 & 26 \\
\hline C-9.01 B & 27.2 & 17 & 2 & $38(-1 ;-4)$ & $38(-2 ;-5)$ & 28 & 27 \\
\hline C- $9.01 \mathrm{C}$ & 44.1 & 21.9 & 2.5 & $41(-3 ;-7)$ & $41(-5 ;-10)$ & 27 & 24 \\
\hline C- $12 \mathrm{~A}$ & 43.5 & 13.5 & 3.4 & $39(-1 ;-4)$ & $39(-2 ;-5)$ & 29 & 28 \\
\hline$C-12 C$ & 41.6 & 11.2 & 3.4 & $38(-1 ;-5)$ & $39(-2 ;-5)$ & 27 & 28 \\
\hline C- $12 \mathrm{D}$ & 26.3 & 7.3 & 1.7 & $42(-2 ;-5)$ & $42(-2 ;-6)$ & 30 & 29 \\
\hline $\mathrm{C}-28 \mathrm{~A}$ & 33.4 & 18.4 & 3.2 & $35(-2 ;-5)$ & $34(-3 ;-7)$ & 25 & 22 \\
\hline C- $28 \mathrm{~B}$ & 23.1 & 7 & 2.1 & $36(-2 ;-6)$ & $34(-2 ;-6)$ & 25 & 23 \\
\hline C- $28 \mathrm{C}$ & 30.9 & 17 & 2.9 & $38(-3 ;-7)$ & $38(-2 ;-6)$ & 26 & 27 \\
\hline C- $28 \mathrm{D}$ & 27.6 & 16.4 & 2.9 & $33(-2 ;-6)$ & $33(-2 ;-6)$ & 22 & 22 \\
\hline$C-4 A$ & 72.0 & 36.3 & 4.9 & $37(-2 ;-5)$ & $39(-2 ;-6)$ & 25 & 26 \\
\hline$C-4 B$ & 37.4 & 18.1 & 1.5 & $32(-1 ;-3)$ & $33(-1 ;-4)$ & 20 & 20 \\
\hline$C-4 C$ & 22.7 & 6.1 & 1.5 & $37(-1 ;-3)$ & $40(-2 ;-5)$ & 27 & 28 \\
\hline C- $5.01 \mathrm{~A}$ & 31.6 & 8.5 & 1.5 & $36(-1 ;-4)$ & $39(-2 ;-6)$ & 24 & 25 \\
\hline C- $5.01 \mathrm{~B}$ & 19.4 & 7.1 & 1.4 & $35(-1 ;-3)$ & $39(-2 ;-6)$ & 26 & 27 \\
\hline C- $14.01 \mathrm{~A}$ & 32.5 & 17.8 & 2 & $37(-2 ;-6)$ & $38(-3 ;-7)$ & 24 & 24 \\
\hline C-14.01 B & 16.9 & 6.3 & 2 & $34(-1 ;-4)$ & $36(-3 ;-6)$ & 26 & 26 \\
\hline C-14.01 C & 24.4 & 15.7 & 2 & $34(-1 ;-4)$ & $35(-1 ;-4)$ & 24 & 25 \\
\hline C-14.01 D & 15.8 & 5.2 & 2 & $35(-1 ;-4)$ & $36(-2 ;-6)$ & 27 & 26 \\
\hline M-5068 B & 21.6 & 6.6 & 0.8 & $29(-1 ;-2)$ & $31(-1 ;-3)$ & 18 & 19 \\
\hline M-5068 C & 31.1 & 18.3 & 0.8 & $33(-1 ;-4)$ & $34(-1 ;-4)$ & 18 & 19 \\
\hline M-5068 D & 27.1 & 16.7 & 0.8 & $33(-1 ;-4)$ & $35(-2 ;-6)$ & 19 & 19 \\
\hline M-5068 E & 31.0 & 6.8 & 0.8 & $36(-2 ;-5)$ & $38(-3 ;-7)$ & 20 & 20 \\
\hline C-47A & 62.6 & 47.6 & 4.4 & $37(-1 ;-4)$ & $39(-2 ;-5)$ & 26 & 27 \\
\hline$C-47 B$ & 34.8 & 19.6 & 1.9 & $39(-2 ;-6)$ & $41(-3 ;-8)$ & 25 & 25 \\
\hline$C-47 C$ & 39.8 & 20.6 & 1.8 & $37(-2 ;-6)$ & $39(-2 ;-7)$ & 23 & 24 \\
\hline$C-47 D$ & 38.8 & 19.3 & 3 & $36(-2 ;-5)$ & $39(-3 ;-7)$ & 25 & 26 \\
\hline$C-47 E$ & 39.6 & 22 & 2.9 & $36(-1 ;-4)$ & $41(-4 ;-8)$ & 26 & 27 \\
\hline $\mathrm{C}-47 \mathrm{~F}$ & 44.3 & 7.2 & 1.9 & $38(-2 ;-6)$ & $40(-2 ;-7)$ & 23 & 24 \\
\hline$C-33 C$ & 28.5 & 17.3 & 1.3 & $35(-1 ;-5)$ & $36(-2 ;-6)$ & 22 & 22 \\
\hline$C-47 G$ & 34.7 & 17.2 & 3.1 & $36(-3 ;-7)$ & $35(-5 ;-10)$ & 24 & 20 \\
\hline C-36.01 B & 34.4 & 19 & 2.3 & $35(-1 ;-4)$ & $36(-2 ;-6)$ & 24 & 23 \\
\hline$C-42 C$ & 30.0 & 8.3 & 2.9 & $31(-1 ;-3)$ & $34(-1 ;-5)$ & 23 & 24 \\
\hline C- $48 \mathrm{~B}$ & 25.5 & 15.9 & 1.4 & $39(-1 ;-4)$ & $41(-2 ;-6)$ & 27 & 27 \\
\hline$C-48 C$ & 26.7 & 16.3 & 1.4 & $39(-1 ;-4)$ & $41(-2 ;-6)$ & 27 & 27 \\
\hline C-59B & 26.8 & 7.45 & 1.47 & $34(-2 ;-4)$ & $37(-3 ;-7)$ & 22 & 22 \\
\hline$C-59 C$ & 25.6 & 7.2 & 1.5 & $33(-1 ;-3)$ & $36(-2 ;-5)$ & 23 & 24 \\
\hline$C-59 E$ & 32.7 & 8.3 & 1.1 & $37(-1 ;-3)$ & $39(-1 ;-4)$ & 24 & 25 \\
\hline$C-49 B$ & 29.8 & 13.2 & 3.4 & $33(-1 ;-3)$ & $34(-1 ;-4)$ & 26 & 26 \\
\hline$C-49 C$ & 24.4 & 6.8 & 1.1 & $37(-1 ;-3)$ & $38(-1 ;-4)$ & 26 & 26 \\
\hline C-49D & 30.0 & 17.1 & 2.3 & $37(-2 ;-5)$ & $37(-1 ;-5)$ & 26 & 26 \\
\hline$C-53 B$ & 41.0 & 11 & 1.3 & $38(-2 ;-5)$ & $40(-2 ;-6)$ & 23 & 24 \\
\hline C-60A & 36.3 & 19.1 & 2.8 & $37(-2 ;-4)$ & $39(-2 ;-6)$ & 27 & 27 \\
\hline C-60B & 29.4 & 7.4 & 2 & $37(-1 ;-3)$ & $37(-1 ;-5)$ & 27 & 25 \\
\hline$C-60 C$ & 35.1 & 18.5 & 2 & $39(-1 ;-4)$ & $39(-1 ;-5)$ & 28 & 27 \\
\hline$V-23 D$ & 29.5 & 7.6 & 1.6 & $37(-1 ;-5)$ & $39(-2 ;-6)$ & 24 & 25 \\
\hline $\mathrm{V}-23 \mathrm{~F}$ & 29.7 & 16.9 & 1.5 & $41(-1 ;-4)$ & $43(-2 ;-5)$ & 29 & 30 \\
\hline M-5081 C & 22.3 & 20.3 & 1.9 & $32(-1 ;-3)$ & $34(-2 ;-6)$ & 23 & 22 \\
\hline M-5081 D & 22.9 & 8.6 & 3.5 & $31(-1 ;-3)$ & $34(-1 ;-5)$ & 25 & 26 \\
\hline M-5060 B & 21.8 & 10.3 & 1 & $33(-1 ;-5)$ & $34(-2 ;-6)$ & 20 & 20 \\
\hline
\end{tabular}


Sliding window, monolithic glass $4 \mathrm{~mm}$. Test: V -9.02 B

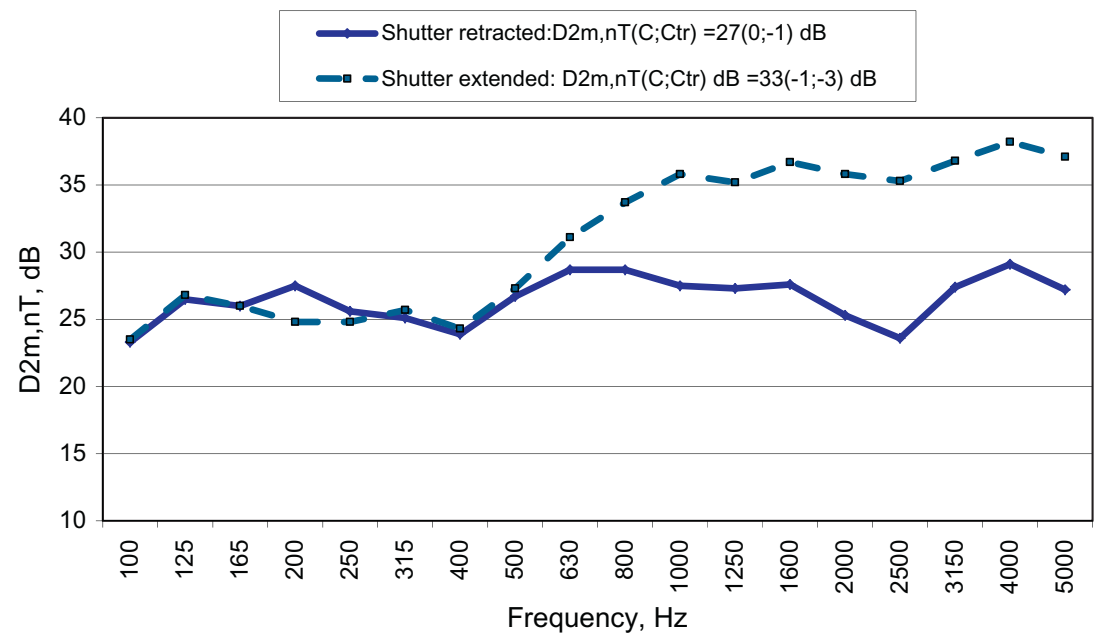

Fig. 2. Comparison of measurements of $D_{2 m, n T}$ on a façade with sliding windows and monolithic glass with the shutter extended and retracted.

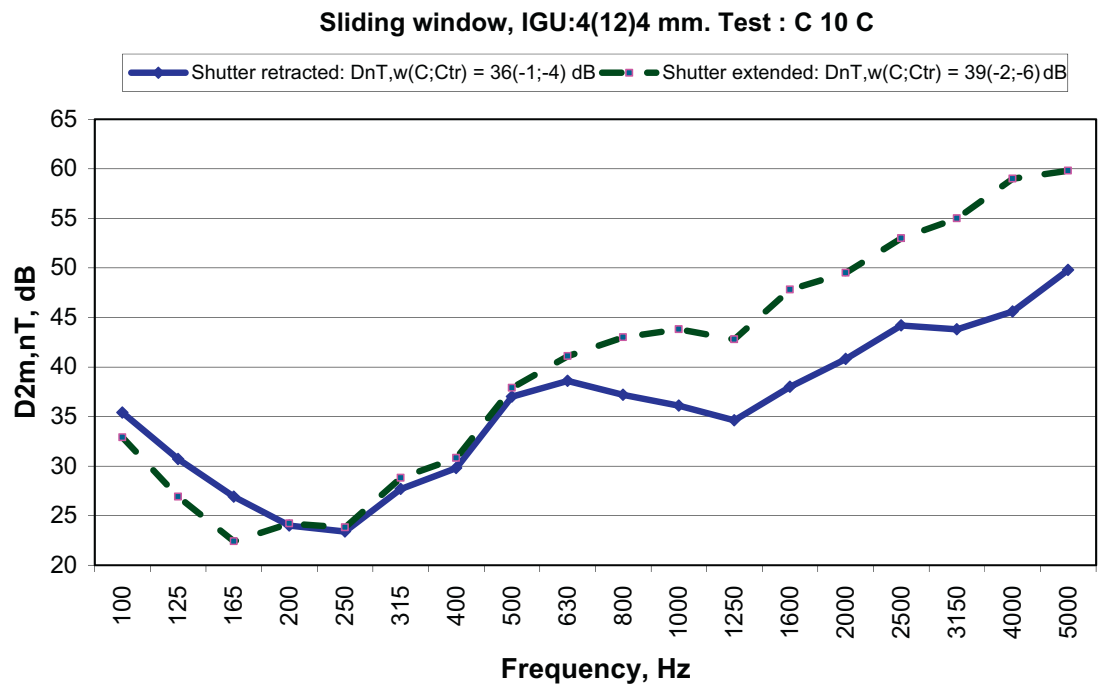

Fig. 3. Façade with sliding windows and IGU; comparison of measurements of $D_{2 m, n T}$ with the shutter extended and retracted.

acoustically like a system with three panels. Taking into account the mass per unit of surface area of the shutter and the panes of glass, in addition to the two distances between the panes of glass and the shutter, the mass-air-mass resonance frequencies [18] are located in the third octave band with a central frequency of $200 \mathrm{~Hz}$ and $500 \mathrm{~Hz}$.

Fig. 3 shows the results of the standardised sound level difference, $D_{2 m, n T}$, for a specific case of a façade with sliding horizontal windows and IGU, when the shutter is fully extended or retracted. For frequencies above $500 \mathrm{~Hz}$ the standardised sound level difference with the shutter extended is substantially higher than when the shutter is retracted.

\subsection{Façades with openable windows and monolithic glass}

This typology is not common in new buildings built within the last 30 years; only six acoustic tests were carried out. The windows are glazed by means of single panes of glass with a thickness of $6 \mathrm{~mm}$. When the shutter is extended, the system functions acoustically like a system of two panels. The mass-air-mass resonance frequency is located in the third octave band, with a central frequency of $200 \mathrm{~Hz}$.
Fig. 4 compares the results of the standardised sound level difference, $D_{2 m, n T}$, for the case of a façade with openable windows and monolithic glass, when the shutter is fully extended or retracted. When the shutter is extended, the effect of stationary waves is detected in low frequencies, and the improvement of the standardised sound level difference with the shutter extended compared to when it is retracted is noticeable above a frequency of $400 \mathrm{~Hz}$.

\subsection{Façades with openable windows and insulating glass unit}

In this typology, 54 acoustic tests were carried out. The thickness of the insulating glass unit was $4(12) 4$ and 6(12)6, in mm. When the shutter is extended the system functions acoustically like a system of three panels. Taking into account the mass per unit of the area of the shutter and the glass panes, in addition to the distance between the panes of glass and the shutter, the massair-mass resonance frequencies are located in the third octave bands with central frequencies of $100 \mathrm{~Hz}, 400 \mathrm{~Hz}$ and $500 \mathrm{~Hz}$.

An example of tests carried out on façades of this type is shown in Fig. 5. It can be seen that the difference in the standardised sound level when the shutter is extended or retracted is minor in frequencies below $500 \mathrm{~Hz}$. 
Openable window, monolithic glass $6 \mathrm{~mm}$. Test: I - $52.02 \mathrm{C}$

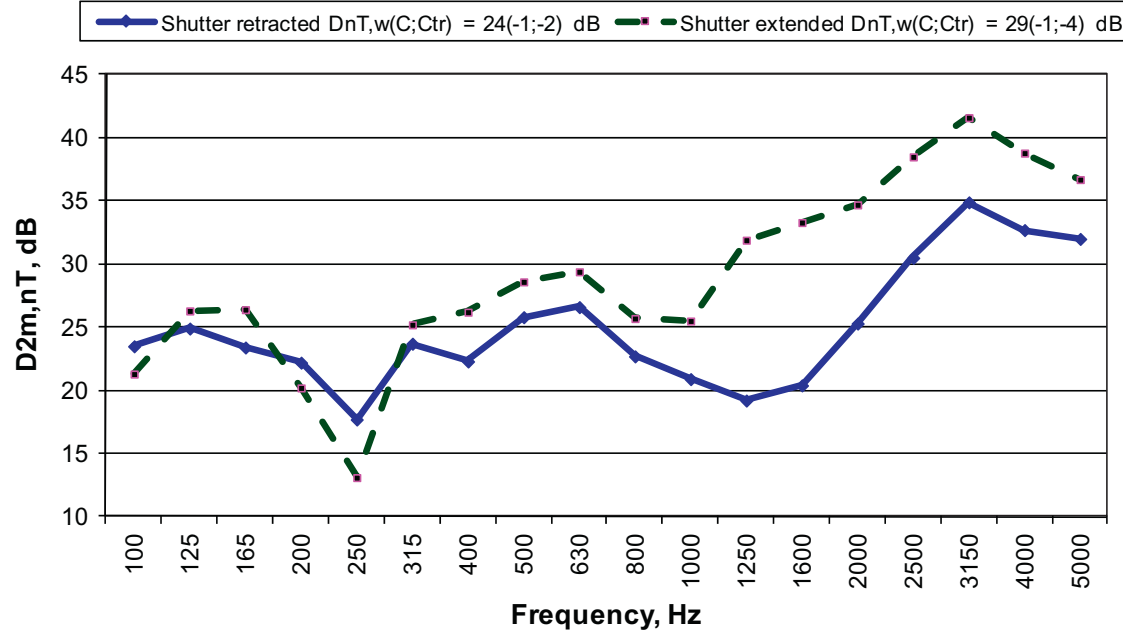

Fig. 4. Shutter extended versus shutter retracted in a façade with openable windows and monolithic glass.

Openable window, IGU: 6(12)6 mm. Test: C-28 A

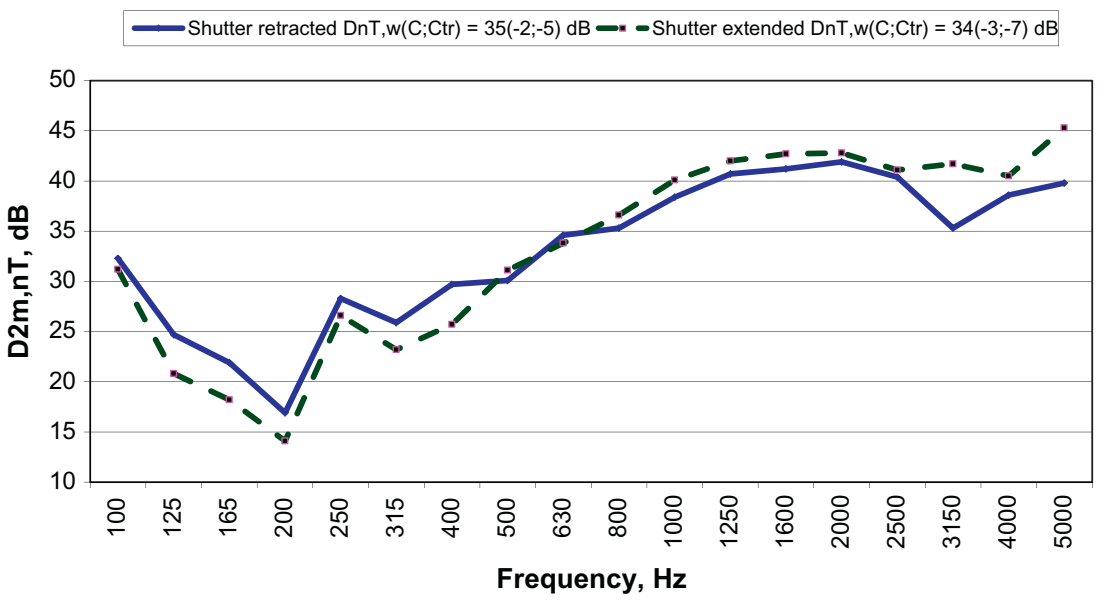

Fig. 5. Façade with openable window and IGU; comparison between the situation with the shutter extended and retracted.

Table 5

Global magnitude $D_{2 m, n T, w}+C_{t r}$ in the different typologies.

\begin{tabular}{|c|c|c|c|c|c|c|c|}
\hline \multirow[t]{2}{*}{ Type of window and glazing } & \multirow[t]{2}{*}{$\begin{array}{l}\text { Number } \\
\text { of tests }\end{array}$} & \multicolumn{2}{|c|}{$\begin{array}{l}\text { Shutter extended } \\
D_{2 m, n T, w}+C_{t r} \mathrm{~dB}\end{array}$} & \multicolumn{2}{|c|}{$\begin{array}{l}\text { Shutter retracted } \\
\underline{D}_{2 m, n T, w}+C_{t r} \mathrm{~dB} \\
\end{array}$} & \multicolumn{2}{|c|}{$\begin{array}{l}\text { Extended - retracted } \\
D_{2 m, n T, w}+C_{t r} \mathrm{~dB} \\
\end{array}$} \\
\hline & & Average & S deviation & Average & S deviation & Average & S deviation \\
\hline Sliding window with monolithic glazing & 20 & 27.8 & 3.5 & 25.3 & 0.7 & 2.6 & 2.8 \\
\hline Sliding window with IGU & 20 & 29.9 & 5.7 & 28.1 & 7.1 & 1.8 & 1.4 \\
\hline Openable window with monolithic glazing & 6 & 24.2 & 1.2 & 23.2 & 0.8 & 1 & 1.4 \\
\hline Openable window with IGU & 54 & 31.7 & 2.1 & 31.8 & 0.7 & -0.1 & 0.7 \\
\hline
\end{tabular}

Finally Table 5, shows the average results and standard deviation of global magnitude $D_{2 m, n T, w}+C_{t r}$ with the shutter extended and retracted, in addition to the differences for the different types of window and glazing.

\section{Conclusions}

This experimental work has been done on around 100 rooms in buildings with flat façades, with windows with built-in shutter boxes installed behind the lintel. The window systems are either openable or horizontal sliding panels, and the type of glass panes are monolithic or insulating glass unit (IGU).

The results obtained in situ show the effect of the position of the shutter either fully extended or retracted - on insulation from airborne noise on the façades of rooms.

When the shutter is fully extended it acts acoustically like a light panel, and the system formed by the panes of glass and the shutter has the mass-air-mass resonance frequencies of the light systems of two or three panels. The effect of stationary waves is detected in the acoustic measurements of the standardised sound level difference, $D_{2 m, n T}$. 
In façades with sliding windows, when the shutter is extended a significant improvement can be seen in the insulation from airborne noise from the central frequency band of $500 \mathrm{~Hz}$, compared to when it is retracted.

In façades with sliding windows and single panes, when the shutter is extended the insulation from airborne noise of the façade improves by an average of over $2.5 \mathrm{~dB}$, compared to when the shutter is retracted. This improvement is reduced to a little under $1.5 \mathrm{~dB}$ when the window is glazed with insulating glass units.

In façades with openable windows and single glass, when the shutter is extended the insulation from airborne noise of the façade improves by $1 \mathrm{~dB}$, compared to when the shutter is retracted. When the windows are openable and with insulating glass units, and the shutter is extended, the insulation from airborne noise of the façade is slightly reduced compared to when the shutter is retracted.

In general, building codes specify the minimum values required to comply with the standardised sound level difference of the façade with traffic noise, and this figure depends significantly on the apparent sound reduction index of the façade. When the windows have a sliding opening mechanism, and the acoustic measurements of the insulation from airborne noise of the façades are taken according to standard UNE-EN ISO 140-5:1999, it is important to indicate whether the measurements have been made with the shutter retracted or extended.

\section{References}

[1] Patricio J, Bragança L. The contribution of roller shutters to noise insulation of façades. Build Acoust 2004;11:309-24.

[2] Asdrubali A Buratti C. Sound intensity investigation of the acoustics performances of high insulation ventilating windows integrated with rolling shutter boxes. Appl. Acoust. 2005;62:307-25.
[3] Díaz C, Pedrero A. An experimental study on the effect of rolling shutter and shutter boxes on the airborne sound insulation of windows. Appl Acoust 2009;70:369-77.

[4] UNE EN ISO 10140-1: 2010. Acoustics. Laboratory measurement of sound insulation of building elements. Part 1: Application rules for specific products.

[5] EN ISO 140-5: 1995. Acoustics. Measurement of sound insulation in buildings and building elements. Part 5: Field measurements of airborne sound insulation of façade elements and façades.

[6] EN 12207 (1999). Windows and doors - Air permeability - Classification.

[7] EN 12354-3:2000. Building acoustics - estimation of acoustic performance of buildings from the performance of elements - Part 3: Airborne sound insulation against outdoor sound.

[8] EN ISO 717-1. Acoustics. Rating of sound insulation in buildings and building elements. Part 1: Airborne sound insulation.

[9] EN ISO 717-1:1996. Acoustics. Rating of sound insulation in buildings and building elements. Part 1: Airborne sound insulation. Amendment 1: rounding rules related to single number ratings and single number quantities [ISO717$1: 1996 /$ AM 1:2006].

[10] EN 20140-2:1993. Acoustics. Measurement of sound insulation in buildings and building elements - Part 2: Determination, verification and application of precision data [ISO 140-2:1991].

[11] Guide to the expression of uncertainty in measurement. International Organization for Standardization; 1995.

[12] Navacerrada MA, Díaz C, Pedrero A, Iglesias L. Calculus of the uncertainty in acoustic field measurements: comparative study between the uncertainty propagation method and the distribution propagation method. Proceedings of Tecniacustica; 2008

[13] Navacerrada MA, Díaz C, Pedrero A. Qualitative behaviour of L1 and L2 standard deviation in insulations measurements according to standard UNE EN ISO 140-4. Proceedings of forum acusticum. Denmark; 2011.

[14] Craik JM. On the accuracy of sound pressure level measurements in rooms Appl Acoust 1990;29:25-33.

[15] Hopkins C. Sound insulation. Oxford: Elsevier; 2007.

[16] Navacerrada MA, Díaz C, Pedrero A. Pressure level standard deviation at low frequencies: effect of the wall vibrational field. Submitted to Archives of Acoustics; 2012.

[17] London A. Transmission of reverberant sound through double walls. J Acoust Soc Am 1950;22(2):270-9.

[18] Vinokur RY. Transmission loss of triple partitions at low frequency. Appl Acoust 1990;29:15-24. 